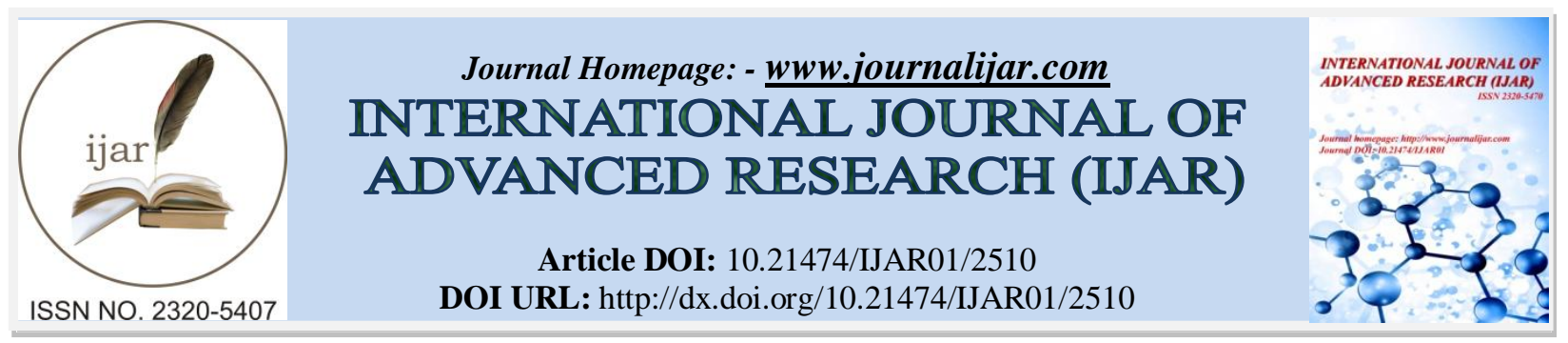

RESEARCH ARTICLE

\title{
ECONOMIC EMPOWERMENT OF WOMEN - A BOOSTER TO FAMILY MEN.
}

\section{Dr. Zenetta Rosaline ${ }^{1}$ and S. Suganya ${ }^{2}$.}

1. Director, Professor, Department of Women's Studies, Bharathiar University, Coimbatore.

2. Research Assistant, Department of Women's Studies, Bharathiar University, Coimbatore.

\section{Manuscript Info}

\section{Manuscript History}

Received: 25 October 2016

Final Accepted: 23 November 2016

Published: December 2016

Key words:-

Men's perception, Women

empowerment, Economic activities of women

\section{Abstract}

Compared to the earlier decade's women are increasingly entering the workforce particularly in the professional works and organized sectors still there remains a large number of invisible women workers in unorganized sectors. Today, many women have established their own economy i.e., entrepreneurial empire and are now ruling their world as they wished to. According to the World Bank 2011 report women perform 66 percent of the world's work, produce 50 percent of the food, but earn 10 percent of the income and own 1 percent of the property. Women usually invest a higher proportion of their earnings in their families and communities than men. Women are becoming empowered in various fields, though still inequality between men and women runs across the board, including in education, economic opportunities, representation in governance, family life and other fields also. Hence the present study aims to identify men's perception towards women economic empowerment.

Copy Right, IJAR, 2016,. All rights reserved.

\section{Introduction:-}

Economic empowerment of women is an indicator of human and social development. Women are being recognized by the world as equivalent to men in almost all occupations. Women's economic participation and empowerment are fundamental to strengthening women's rights and enabling women to have control over their lives and exert influence in society. Our Indian constitution Article 14 deals - Men and women to have equal rights and opportunities in the political, economic and social spheres. But practically speaking it is very difficult to achieve gender equality in all spheres of our Indian society. According to United Nations statistics: Women earn ten percentage of world's income and also they own less than one percent of world's property. India has one of the highest world percentages of professional women, less than $3 \%$ of women occupy managerial positions. AmartyaSen (2001) states "Nothing, arguably, is as important today in the political economy of development as an adequate recognition of political, economic and social participation and leadership of Women". Recently, the 2012 World Development Report highlighted the importance of women's empowerment and gender equality work as both ends in themselves as well as 'smart economics' - a key lever for development impact and poverty reduction. Financial Independence is an important step towards empowerment of women. In the last two decades; working women have made great strides toward economic equality with men. Most women work in low administrative positions and many of the young women migrating to urban centers mostly work in service and retail industries, although more women are entering the IT and other technical sectors. On equal economic opportunities and women's participation in the labor force, India ranked 127th and 122nd respectively. In the educational field about 30 percent of the teachers at the primary and at the secondary level are women. Making the most of the talent pool 
ensures that men and women have an equal chance to contribute both at home and in the workplace, thereby enhancing their well-being and that of society.

\section{Women's Economic participation - Statistical report:-}

$>$ Globally, women represent $49.6 \%$ of the total population, but only $40.8 \%$ of the total workforce in the formal sector.

$>$ Women perform 66 percent of the world's work, produce 50 percent of the food, but earn 10 percent of the income and own 1 percent of the property. (Women, Business and the Law, World Bank, 2011)

$>$ National Sample Survey (68th Round) results indicate that the worker population ratio for females in rural sector was 24.8 and 54.3 for males. In Urban sector, the ratio is 14.7 for females and 54.6 for males in 2011-12.

$>$ According to United Nations statistics: Women earn ten percentage of world's income and also they own less than one percent of world's property.

$>$ As per Census 2011, the workforce participation rate for females is $25.51 \%$ against $53.26 \%$ for males. Rural sector has a better female workforce participation rate of $30.02 \%$ compared with $53.03 \%$ for males whereas for urban sector.

$>$ A total of $20.5 \%$ women were employed in the organized sector in 2011 with $18.1 \%$ working in the public sector and $24.3 \%$ in the private.

$>$ In tamilnadu according to census 2011 work force participation rate of female is $31.80 \%$. Among major states, Tamil Nadu reported the highest number of women jobseekers (540.1 thousand).

$>$ Worker population ratio in the year of 2011 and 2012 in rural in Tamilnadu 37.8 for females 59.5 for males, in urban sector 20.1 for females 58.7 for males.

$>$ In the year of 2011 tamilnadu plays $14^{\text {th }}$ rank in the state wise female work participation rate.

\section{Objectives:-}

$>$ To identify the men's perception on the economic empowerment of women.

$>$ To access the role of economic empowerment of women in running family issues.

$>$ To define the women's role in decision making power in family life.

\section{Scope of the Study:-}

The scope of the study is that, it establishes in identifying men's perception on women's economic empowerment. The study intends to provide knowledge regarding the key variables that influence, responsible for maintaining the structure of women's decision making and handling the ways of family issues. The research outcome could be used for men to have awareness on empowering women in the society and in their family.

\section{Literature Review:-}

1. According to James Heintz (2012) Working women are disproportionally engaged in the informal economy. The informal economy is heterogeneous and stratified, and there is a close association between the quality of jobs and gender - with men dominating the upper echelons of the hierarchy and women over-represented in the lower echelons - along with other markers of social inequality, like caste, ethnicity, race, and legal status.

2. Women owning property have a greater say in decisions regarding their employment, accessing health facilities for themselves, and use of their money. (Hema Swaminathan, Rahul Lahoti and Suchitra J.Y.2012)

3. According to Tornquvist \& Schmitz (2009), Women's economic empowerment defined it as 'the process which increases women's real power over economic decisions that influence their lives and priorities in society. Women's economic empowerment can be achieved through equal access to and control over critical economic resources and opportunities, and the elimination of structural gender inequalities in the labour market including a better sharing of unpaid care work.

4. According to Briges, Das et al (2011), it is clear that poverty is a major factor driving women's labour force participation rates. While there is some regional variation in the economic activity rates of women from more affluent households, women from poorer households in most regions are either economically active or seeking to become so. In cultures like South Asia where there are strict norms of female seclusion, there is in fact a strong association between household poverty and women's labour force participation (Bennett, 1992; Das , 2006; Srivastava and Srivastawa, 2009; Sathar and Desai, 1996 for Pakistan; Hossain and Sen, 1991; Bridges et al 2011 for Bangladesh). 


\section{Methodology Adopted:-}

The study is descriptive in nature. Working Men (their spouse working in these three sectors respectively Teaching, Information technology and Bank) in Coimbatore were selected for the study. From each sector 20 respondents were selected randomly. Totally 60 respondents were selected for this study. The participants responded on a 5-point Likert-type scale, anchored by Strongly Agree (5 point) and Strongly Disagree (1 point) for positive statements and for negative statements Strongly Agree (1 point) and Strongly Disagree (5 point) for each item. The tools used for data collection was based on review of literature. The collected data was analyzed using SPSS.

Table 1:- Personal Profile of the Respondents

\begin{tabular}{|c|c|c|c|c|c|}
\hline S.No & Variables & Category & Percentage & Mean & SD \\
\hline 1 & Age & $\begin{array}{l}25 \text { years to } 34 \text { years } \\
35 \text { years to } 44 \text { years } \\
45 \text { years \& above }\end{array}$ & $\begin{array}{l}35.0 \\
40.0 \\
25.0\end{array}$ & 1.90 & .775 \\
\hline 2 & Education & $\begin{array}{l}10^{\text {th }} \text { Standard } \\
12^{\text {th }} \text { Standard } \\
\text { Diploma } \\
\text { Under graduate } \\
\text { Post graduate } \\
\text { Professional degree }\end{array}$ & $\begin{array}{c}15.0 \\
5.0 \\
15.0 \\
26.7 \\
26.7 \\
11.7\end{array}$ & 3.60 & 1.554 \\
\hline 3 & Occupation & $\begin{array}{l}\text { Unorganized sector } \\
\text { Organized sector } \\
\text { Own Business }\end{array}$ & $\begin{array}{l}23.3 \\
55.0 \\
21.7\end{array}$ & 1.98 & .676 \\
\hline 4 & Monthly Income & $\begin{array}{l}\text { Rs. } 10,000 \text { to } 20,000 \\
\text { Rs. } 20,001 \text { to } 30,000 \\
\text { Rs.30,001 to } 40,000 \\
\text { Rs. } 40,001 \& \text { above }\end{array}$ & $\begin{array}{c}30.0 \\
33.3 \\
30.0 \\
6.7 \\
\end{array}$ & 2.13 & .929 \\
\hline 5 & Spouse Education & $\begin{array}{l}10^{\text {th }} \text { Standard } \\
12^{\text {th }} \text { Standard } \\
\text { Diploma } \\
\text { Under graduate } \\
\text { Post graduate } \\
\text { Professional degree }\end{array}$ & $\begin{array}{c}5.0 \\
5.0 \\
11.7 \\
40.0 \\
30.0 \\
8.3\end{array}$ & 3.67 & 1.230 \\
\hline 6 & Total family Income & $\begin{array}{l}\text { Up to Rs. } 40,000 \\
\text { Rs. } 40,001 \text { to } 60,000 \\
\text { Rs.60,001 to } 80,000 \\
\text { Rs. } 80,001 \text { to Rs. } 1,00000 \\
\text { Rs. } 1,00001 \& \text { above }\end{array}$ & $\begin{array}{c}43.3 \\
33.3 \\
15.0 \\
6.7 \\
1.7\end{array}$ & 1.90 & 1.003 \\
\hline 7 & Type of Family & $\begin{array}{l}\text { Nuclear family } \\
\text { Joint family }\end{array}$ & $\begin{array}{l}60.0 \\
40.0 \\
\end{array}$ & 1.40 & .494 \\
\hline 8 & Number of Children & $\begin{array}{l}\text { One children } \\
\text { Two children } \\
\text { Three children } \\
\text { Nil }\end{array}$ & $\begin{array}{c}28.3 \\
35.0 \\
6.7 \\
30.0 \\
\end{array}$ & 1.18 & .948 \\
\hline
\end{tabular}

As observed from the above table 1, two-fifth of the respondents was in the age group of 35 years to 44 years. More than half of the respondents are educated up to under graduation level and post graduation level. More than half of the respondents are working in organized sector. One-third of the respondent's income level is between Rs.20, 001 and Rs.30, 000. Two-fifth of the respondent's spouse was educated up to under graduation level. Nearly half of the respondent's total family income is up to Rs. 40, 000. More than half of the respondents are in Nuclear family. More than one-third of the respondents are having two children. 
Table 2:- Chi Square Results.

\begin{tabular}{|l|c|}
\hline \multicolumn{1}{|c|}{ Variables } & Economic Empowerment \\
\hline Age & .175 \\
\hline Education & .053 \\
\hline Occupation & .031 \\
\hline Monthly Income & .008 \\
\hline Spouse Education & .009 \\
\hline Spouse Occupation & .003 \\
\hline Total family Income & .228 \\
\hline Type of Family & .549 \\
\hline Number of Children & .336 \\
\hline
\end{tabular}

The above table -2 shows that women's economic empowerment has significance difference in association with occupation, monthly income, spouse education and spouse occupation of the male respondents.

Table 3:-

\begin{tabular}{|l|c|}
\hline Economic Empowerment of Women & Percentage \\
\hline Low (44 to 54) & 10.0 \\
\hline Moderate (55 to 64) & 41.7 \\
\hline High (65 and above) & 48.3 \\
\hline
\end{tabular}

The above table 3 shows that nearly half of the respondents felt that women should enhance in economic empowerment for the better of the family and society.

\section{Conclusion:-}

Economic empowerment of women develops the family as well as the society. In the present scenario, men have awareness on importance of economic empowerment of women. Hence they are willing to encourage women for their economic empowerment. The result shows that nearly half of the respondents felt that women should be enhanced in economic empowerment for the better of the family and society.

\section{References:-}

1. Bridges, S., D. Lawson and S. Begum (2011) 'Labor market outcomes in Bangladesh: the role of poverty and gender norms’ European Journal of Development Research Vol. 23 (3): 459-487.

2. Hema Swaminathan,Rahul Lahotia and Suchitra J.Y.2012Women's Porperty Mobility and Decision -making evidence from Rural Karnataks,India IFPRI Discussion paper 01188.

3. Jütting and Laiglesia (2009); Chen (2008, 2012); SIG working paper by James Heintz (2012).

4. Sathar, Z. and S. Desai (1996) Work patterns in rural Pakistan: intersections between gender, family and class Research Division WorHossain, M. and B. Sen (1991) 'Determinants of poverty' in H.Z. Rahman and M. Hossain (eds) Rethinking rural poverty: Bangladesh as a case study New Dehli: Sage Publications king Papers No. 90. New York: Population Council.

5. Srivastava, N. and R. Srivastava (2009) Women, work and poverty inter-links in rural India Paper presented at FAO-IFAD-ILO Workshop on Gaps, trends and current research in the gender dimensions of agricultural and rural employment: differentiated pathways out of poverty March 31-April 2nd. Rome

6. Tornqvist, A. and C. Schmitz (2009) Women's economic empowerment: scope for Sida's engagement Working Paper December. Stockholm: SIDA

7. UNICEF, The State of the World's Children at 12-14. 